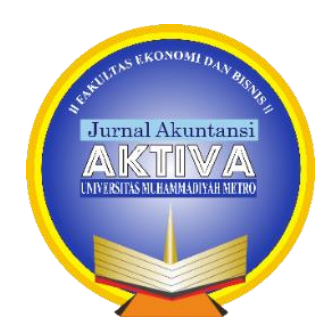

Jurnal Akuntansi AKTIVA, Vol 1, No 2, Oktober 2020

\title{
PENGARUH UPAH MINIMUM REGIONAL DAN RASIO INFRASTRUKTUR TERHADAPKESENJANGAN DISTRIBUSI PENDAPATAN DI INDONESIA
}

\author{
Siti Nurul Noviana \\ Universitas Lampung, J1. Prof. Dr. Ir. Sumantri Brojonegoro, 35141, Bandar Lampung, Indonesia \\ sitinurul.noviana@gmail.com
}

\begin{abstract}
This study aims to examine the impact of region minimum wage and infrastructure ratio onIncome Distribution Gap in Indonesia. This study uses panel data for the period 2011-2017 and consists of 33 provinces, except North Kalimantan Province because it is a new province. By using fixed effect panel data regression analysis, with dependent variable is gini index. While independent variable are regional minimum wage and infrastructure ratio.On the one hand, based on hypothetical test, the results show that the regional minimum wage and infrastructure ratio have a negative and significant effect on the income distribution gap in Indonesia. On the other hand, based on the individual effects test, the large islands such as Sumatera, Java, Kalimantan, Sulawesi, Bali, Maluku, and Papua have a positive effect on the gini ratio. This shows that there is an impact of the infrastructure ratio function and regional minimum wages in increasing the distribution of income as measured by the gini index.
\end{abstract}

Keywodrs : income distribution gap, regional minimum wages, infrastructure ratio.

\begin{abstract}
ABSTRAK
Penelitian ini bertujuan untuk mengetahui pengaruh Upah Minimum Regional dan Rasio Infrastruktur terhadap Kesenjangan Distribusi Pendapatan di Indonesia. Data yang digunakan adalah data panel yang terdiri dari data cross section tahun 2011 - 2017 dan time series yang terdiri dari 33 provinsi di Indonesia, namun Provinsi Kalimantan Utara tidak dimasukkan karena merupakan provinsi baru. Alat analisis yang digunakan adalah analisis regresi data panel Fixed Effect dengan variabel dependen adalah Indeks Gini. Sedangkan variabel independen yaitu, Upah Minimun Regional Provinsi dan Rasio Infrastruktur. Dari pengujian hipotesis diperoleh hasil bahwa Upah Minimun Regional dan Rasio Infrastruktur berpengaruh negatif dan signifikan terhadap Kesenjangan Distribusi Pendapatan di Indonesia. Sedangkan hasil dari individual effect, pulau-pulau besar seperti Sumatera, Jawa, Kalimantan, Sulawesi, Bali, Maluku, dan Papua memiliki nilai efek positif terhadap rasio gini. Hal ini menunjukkan bahwa adanya pengaruh fungsi rasio infrastruktur dan upah minimum regional dalam meningkatkan distribusi pendapatan yang diukur melalui indeks gini.
\end{abstract}

Kata Kunci : kesenjangan distribusi pendapatan, upah minimum regional, rasio infrastruktur. 


\section{PENDAHULUAN}

Taraf hidup atau kesejahteraan seluruh rakyat melalui peningkatan pembangunan ekonomi suatu negara merupakan tujuan utama yang ingin dicapai setiap negara di dunia. Pembangunan ekonomi merupakan suatu keharusan jika suatu negara ingin meningkatkan taraf hidup dan kesejahteraan rakyatnya. Dengan kata lain, pembangunan ekonomi merupakan upaya sadar dan terarah dari suatu bangsa untuk meningkatkan kesejahteraan rakyatnya melalui pemanfaatan sumberdaya yang ada. Peningkatan kesejahtaraan ini antara lain dapat diukur dari kenaikan tingkat pendapatan nasional atau laju pertumbuhan ekonomi yang tinggi setiap tahunnya (Sukirno, 2006).

Selain pertumbuhan ekonomi, kesenjangan pendapatan (income inequality) juga menjadi isu penting bagi pembangunan setiap negara. Secara teoritis dan didukung oleh banyak peneliti empiris terbukti bahwa pertumbuhan ekonomi yang tinggi berdampak pada kesenjangan pendapatan. Kesenjangan pendapatan berkaitan dengan distribusi pendapatan yang diterima oleh masyarakat di suatu negara.Semakin tinggi kesenjangan pendapatan berarti distribusi pendapatan dimasyarakat semakin tidak merata. Kondisi ini pada akhirnya akan memperbesar kesenjangan (gap) antara masyarakat dengan tingkat ekonomi relatif baik (kelompok kaya) dengan mereka yang berpendapatan rendah (kelompok miskin) (Amri, 2017).

Beberapa ukuran kesenjangan yang sering digunakan antara lain: Indeks Gini, Indeks Theil dan ukuran kesenjangan dari Bank Dunia. Dalam penelitian ini ukuran kesenjangan yang digunakan adalah Indeks Gini.Indeks Gini adalah suatu ukuran kesenjangan yang paling sering digunakan untuk mengukur kesenjangan dan ukuran kesenjangan agregat yang nilainya berkisar antara nol dan satu (Damanik, 2018).

Rasio atau Koefisien Gini, yang mengukur ketidakmerataan distribusi pendapatan, merupakan indikator penting untuk menilai tingkat pemerataan pembangunan di suatu negara. Koefisien gini 0 (nol) menunjukkan kemerataan sempurna, sedangkan koefisien gini 1 (satu) menunjukkan ketidakmerataan sempurna. Tingkat ketidakmerataan yang tinggi dimasyarakat merupakan ancaman karena tidak hanya membahayakan kondisi sosial suatu bangsa namun juga membahayakan stabilitas politik dan ekonomi bangsa tersebut. Selain itu, penelitian yang dilakukan oleh Bank Dunia menunjukkan bahwa negara-negara dengan distribusi pendapatan yang merata cenderung tumbuh lebih cepat dan lebih stabil dibandingkan dengan negara-negara yang menunjukkan tingkat kesenjangan pendapatan yang tinggi. 


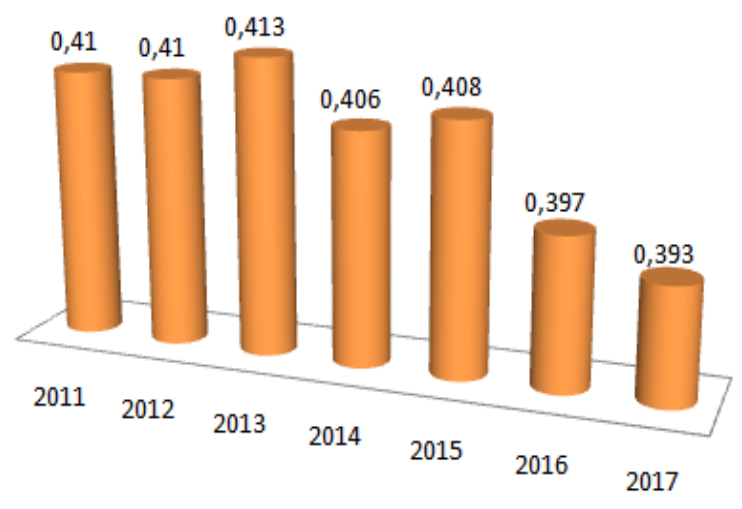

Sumber: Susenas Maret 2016-2017, (Diolah)

Gambar 1. Rasio Gini Indonesia Tahun 2011 - 2017

Melihat kesenjangan yang terjadi dalam kurun waktu tahun 2011-2017 seperti yang digambarkan pada Gambar 1. maka kita akan dapat melihat kenaikan pada rasio gini. Dapat dilihat bahwa rata-rata nilai rasio gini Indonesia pada tahun 2011-2017 sebesar 0,405. Dari tahun 2011 ke 2012, rasio gini tidak mengalami kenaikan maupun penurunan. Setelah tahun 2012 tingkat kesenjangan meningkat menjadi diatas sebelumnya menjadi sebesar 0,413 di tahun 2013. Rasio gini mengalami penurunan dari sebelumnya 0,408 tahun 2015 menjadi 0,397 di tahun 2016 dan menjadi 0,393 di tahun 2017. Kenaikan dan penuruan rasio gini yang terjadi telah memberikan dampak yang cukup signifikan dalam paradigma kesenjangan pendapatan penduduk di Indonesia. Pasca krisis keuangan global yang terjadi tahun 2008, rasio gini Indonesia tahun 2011 hingga 2015 mengalami tren peningkatan.

Terdapat beberapa penelitian mengenai faktor-faktor yang mempengaruhi kesenjangan distribusi pendapatan. Alasan untuk peneliti ingin melihat faktor-faktor yang mempengaruhi kesenjangan distribusi pendapatan adalah karena ketidakmerataan ekonomi telah menjadi perdebatan dalam isu sosial-ekonomi dunia sehingga penyebab dan akibat dari suatu kesenjangan distribusi pendapatan harus dipertimbangkan, dianalisis dan dikurangi. Selain itu, faktor-faktor yang mempengaruhi kesenjangan distribusi pendapatan secara teoritis dan empiris masih ambigu karena terdapat berbagai hasil penelitian yang berbeda mengenai faktor-faktor yang mempengaruhi kesenjangan pendapatan. Data dan metode statistik yang berbeda akan mendapatkan hasil yang berbeda pula. Sehingga dapat disimpulkan bahwa faktor-faktor yang mempengaruhi kesenjangan distribusi pendapatan berbeda case by case nya (Tsen, 2014).

Sebagian penelitian menunjukkan bahwa pertumbuhan ekonomi berdampak negatif terhadap kesenjangan pendapatan seperti penelitian yang dilakukan oleh Binalti (2012), Bantika (2015), Pangemanan (2001), Amri (2017), dan Waluyo (2006) artinya pertumbuhan ekonomi akan menurunkan kesenjangan pendapatan. Sehingga dapat disimpulkan bahwa pemerataan yang lebih adil di negara berkembang merupakan suatu kondisi atau syarat yang menunjang pertumbuhan ekonomi.

\section{Jurnal Akuntansi AKTIVA}


Dengan demikian, semakin timpang distribusi pendapatan di suatu negara akan berdampak negatif terhadap pertumbuhan ekonomi.

Sebaliknya, hasil yang berbeda ditunjukkan dari penelitian yang dilakukan oleh Nuraini (2017), Rosa (2016), Putri (2016), dan Wahiba (2014) bahwa pertumbuhan ekonomi berpengaruh positif terhadap disparitas pendapatan. Sehingga ketika terjadi peningkatan output dari beberapa indikator pertumbuhan ekonomi, peningkatan tersebut tidak dapat terdistribusi secara merata pada setiap lapisan masyarakat dan hanya terkonsentrasi pada golongan masyarakat kelas atas atau para pemilik modal. Hal tersebut yang menyebabkan tingginya pertumbuhan ekonomi tidak dapat menurunkan disparitas pendapatan.

Kuznets (1995) menyatakan bahwa hubungan antara pertumbuhan ekonomi dan kesenjangan pendapatan berbentuk $U$ terbalik, dimana pada awalnya peningkatan pertumbuhan ekonomi dapat meningkatkan kesenjangan pendapatan.Setelah mencapai kondisi tertentu, peningkatan pendapatan justru menurunkan kesenjangan pendapatan (Amri, 2012).

Salah satu penyebab kemiskinan di Indonesia adalah ketersediaan lapangan pekerjaan yang menyebabkan tingginya tingkat pengangguran di Indonesia. Selain itu, karena tingkat penawaran tenaga kerja melebihi tingkat permintaannya, maka akan menyebabkan upah buruh menurun.

Upah minimum di Indonesia diatur untuk meningkatkan standar hidup pekerja dan jaring pengaman, yang bertujuan untuk melindungi pekerja dengan upah rendah.Isu tentang dampak upah minimum terhadap kemiskinan masih menjadi masalah yang diperdebatkan.Beberapa ekonom berpendapat aturan upah minimum mengenai upah minimum dapat meningkatkan kondisi ekonomi pekerja berupah rendah, sehingga berkontribusi pada pengurangan kemiskinan pekerja yang terkena aturan ini. Disisi lain, upah minimum dapat menyebabkan kekakuan di pasar tenaga kerja dan daya saing yang lebih rendah. Kekakuan upah yang disebabkan oleh upah minimum dapat memperlambat penciptaan pekerjaan dan pada gilirannya berkontribusi pada pengangguran dan kemiskinan.

Untuk mengurangi besarnya kesenjangan pendapatan, strategi pembangunan tidak hanya menitikberatkan pada pertumbuhan ekonomi melainkan dengan menciptakan pertumbuhan yang inklusif pada setiap daerah di Indonesia. Pola pertumbuhan inklusif memaksimalkan potensi ekonomi dan menyertakan sebanyak-banyaknya angkatan kerja dalam pasar tenaga kerja yang baik (Decent Work) sehingga dapat mengurangi angka kemiskinan dan ramah keluarga miskin sehingga mendorong perbaikan pemerataan, dan pengurangan kesenjangan.Terciptanya dukungan terhadap perekonomian inklusif dapat mendorong pertumbuhan di berbagai sektor pembangunan, seperti pertanian, industri, dan jasa, untuk menghindari pertumbuhan yang cenderung ke sektor padat modal dan bukan padat tenaga kerja.

Masalah lain tentang kesenjangan distribusi pendapatan, salah satu penyebabnya adalah perbedaan pembangunan infrastruktur. Menurut World Economic Forum, infrastruktur yang luas dan efisien sangat penting untuk memastikan berfungsinya ekonomi secara efektif, karena itu merupakan faktor penting dalam menentukan lokasi kegiatan ekonomi dan jenis kegiatan atau sektor yang dapat 119 | Jurnal Akuntansi AKTIVA 
berkembang di suatu negara. Infrastruktur yang dikembangkan dengan baik akan mengurangi efek jarak antar wilayah, mengintegrasikan pasar nasional dan menghubungkannya dengan biaya yang rendah di negara dan wilayah lain. Selain itu, kualitas dan ekstensi jaringan infrastruktur secara signifikan berdampak pada pertumbuhan ekonomi dan mengurangi ketidaksetaraan pendapatan dan kemiskinan dalam berbagai cara.

Perannya infrastruktur dalam pengembangan suatu wilayah sangatlah penting terutama pengembangan infrastruktur jalan. Jalan merupakan infrastruktur pendukung mobilitas masyarakat dalam melakukan kegiatan ekonomi, sosial dan budaya, serta pertahanan dan keamanan. Peningkatan infastruktur jalan dapat berdampak pada peningkatan ekonomi disuatu wilayah. Untuk mengevaluasi manfaat jalan maka dilakukan peritungan rasio pada bagian ini. Panjang jalan yang dihitung adalah panjang jalan nasional (tidak termasuk jalan tol), jalan provinsi, jalan kabupaten, dan jalan kota.

Pada penelitian Prasetyo dan Firdaus (2009) menunjukkan bahwa kontribusi infrastruktur baik listrik, jalan, maupun air bersih berpengaruh positif dan signifikan terhadap pertumbuhan ekonomi. Artinya, dengan meningkatnya kontribusi infrastruktur akan meningkatkan pertumbuhan ekonomi yang berdampak pada kesenjangan pendapatan suatu daerah atau wilayah. Sebaliknya penurunan kontribusi infrastruktur akan menurunkan pertumbuhan ekonomi.Namun berbeda dengan hasil penelitian yang dilakukan Sibarani (2002) yang menyimpulkan bahwa kontribusi infrastruktur dalam hal ini jalan, memiliki pengaruh yang tidak signifikan terhadap pertumbuhan ekonomi.

Di Indonesia kesenjangan pada kenyataannya tidak dapat dihilangkan dalam pembangunan suatu daerah. Adanya kesenjangan, tentu akan memberikan dorongan kepada daerah-daerah yang terbelakang untuk dapat berusaha meningkatkan kualitas hidupnya agar tidak jauh tertinggal dengan daerah sekitarnya. Sehingga daerah-daerah tersebut yang akan bersaing guna meningkatkan kualitas hidupnya, sehingga kesenjangan dalam hal ini memberikan dampak positif. Penetapan upah minimum akan menciptakan ketimpangan pendapatan.

Jika infrastruktur meningkat baik dari aspek kuantitas dan kualitas maka dapat mendorong meningkatnya roda perekonomian khususnya transportasi barang dan jasa. Dengan meningkatnya roda atau kegiatan perekonomian di suatu wilayah maka akses masyarakat untuk memperoleh pendapatan juga meningkat. Dengan meningkatnya pendapatan tersebut maka seharusnya kesenjangan distribusi pendapatan di wilayah tersebut juga berkurang ceteris paribus.

Upaya mempercepat pembangunan ekonomi selain dengan mengingkatkan tingkat upah juga dapat dilaksanakan dengan meningkatkan pertumbuhan ekonomi dan tingkat produktivitasnya karena meningkatkan tingkat upah yang terlalu tinggi akan turut membebani perekonomian karena biaya untuk tenaga kerja cukup tinggi dan menghambat investor untuk melakukan akselerasi memperluas usahanya sehingga harus seefisien mungkin. Efisiensi dalam kegiatan ekonomi harus didukung oleh infrastruktur yang memadai sehingga mendorong peningkatan potensi daerah masing-masing secara berkesinambungan. Walaupun kebijakan pembangunan infrastruktur di Indonesia telah berlangsung cukup lama dengan biaya yang cukup besar dan kontribusinya dalam peningkatan pertumbuhan $\mathbf{1 2 0}$ | Jurnal Akuntansi AKTIVA 
ekonomi cukup signifikan, namun masih banyak masalah yang dihadapi beberapa wilayah di Indonesia, antara lain perencanaan yang lemah, kuantitas yang belum mencukupi dan kualitas yang masih rendah (Ikhsan 2004).

Berdasarkan latar belakang yang telah diuraikan di atas, maka masalah dalam penelitian ini dapat dirumuskan sebagai berikut:

1. Apakah upah minimum regional berpengaruh terhadap kesenjangan distribusi pendapatan di setiap provinsi di Indonesia?

2. Apakah rasio infrastruktur berpengaruh terhadap kesenjangan distribusi pendapatan di setiap provinsi di Indonesia?

\section{LANDASAN TEORI}

Teori Pendapatan dan Distribusi Pendapatan

Menurut Ilmu Ekonomi, pendapatan adalah nilai maksimum yang dapat dikonsumsi seseorang dalam suatu periode dengan mengharapkan keadaan yang sama pada akhir periode seperti keadaan semula. Pengertian pendapatan menurut Ilmu Ekonomi menitikberatkan pada total kuantitatif pengeluaran terhadap konsumsi selama satu periode. Dengan kata lain, pengertian pendapatan menurut Ilmu Ekonomi adalah jumlah harta kekayaan awal periode ditambah keseluruhan hasil yang diperoleh selama satu periode, bukan hanya yang dikonsumsi serta bukan diakibatkan oleh perubahan modal dan hutang (Wild, 2003).

Sukirno (2006) menjelaskan bahwa pendapatan adalah sejumlah penghasilan yang diperoleh masyarakat atas prestasi kerjanya dalam periode tertentu, baik harian, mingguan, bulanan maupun tahunan. Sedangkan Rahardja dan Manurung (2001) mendefinisikan pendapatan sebagai total penerimaan seseorang atau suatu rumah tangga dalam periode tertentu. Sehingga dapatdisimpulkan bahwa pendapatan merupakan penghasilan yang diterima oleh masyarakat berdasarkan kinerjanya, baik pendapatan uang maupun bukan uang selama periode tertentu, baik harian, mingguan, bulanan maupun tahunan.

Distribusi pendapatan merupakan suatu permasalahan yang sangat penting dalam sebuah perekonomian, karena hal tersebut merupakan indikator keberhasilan pembangunan ekonomi. Sebuah negara yang pertumbuhan ekonominya tinggi namun distribusi pendapatannya tidak merata, maka pertumbuhan ekonomi yang tinggi tersebut tidak dapat menciptakan kesejahteraan masyarakatnya. Pendapatan sangat penting dan perlu untuk diperhatikan dalam sebuah negara, namun yang lebih penting adalah carapen distribusiannya.

\section{Kesenjangan Pendapatan}

Permasalahan kesenjangan pendapatan secara teoritis dimunculkan oleh Douglas C. North dalam analisisnya tentang teori pertumbuhan Neo Klasik.Dalam teori tersebut dimunculkan prediksi tentang hubungan antara tingkat pembangunan ekonomi nasional suatu negara dengan kesenjangan pendapatan antar wilayah. Hipotesis ini menyatakan bahwa pada permulaan proses pembangunan 121 Jurnal Akuntansi AKTIVA 
suatu negara, kesenjangan pendapatan akan meningkat. Proses ini akan terjadi sampai kesenjangan tersebut mencapai titik puncak. Setelah itu bila proses pembangunan terus berlanjut maka secara berangsur-angsur kesenjangan pendapatan antar wilayah tersebut akan menurun. Berdasarkaan hipotesis ini dapat ditarik kesimpulan sementara bahwa pada negara sedang berkembang umumnya kesenjangan pendapatan antar wilayah cenderung tinggi, sedangkan pada negara maju ketimpangaan akan menjadi lebih rendah (Sjafruzal, 2012).

\section{Pengaruh Kesenjangan Pendapatan}

Simon Kuznets (1955) mengatakan bahwa pada tahap awal pertumbuhan ekonomi, distribusi pendapatan cenderung memburuk, namun pada tahap selanjutnya, distribusi pendapatannya akan membaik. Penelitian ini kemudian dikenal sebagai kurva Kuznets "U-terbalik", dimana perubahan longitudinal (time-series) dalam distribusi pendapatan yang dapat dilihat pada Gambar 3. Kurva Kuznets dihasilkan dari perluasan sektor modern sebagai proses pertumbuhan yang berkesinambungan.

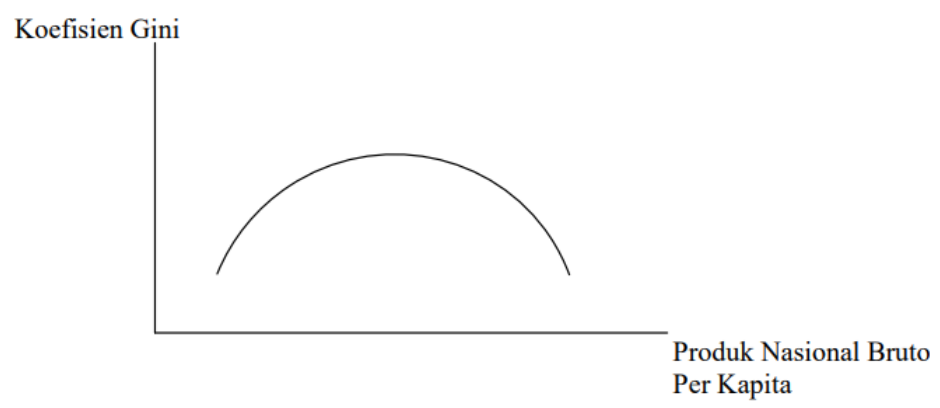

\section{Gambar 2. Kurva Kuznets "U Terbalik"}

Menurut Todaro (2003), pemerataan yang lebih adil di negara berkembang merupakan suatu kondisi atau syarat yang menunjang pertumbuhan ekonomi. Artinya, semakin besar kesenjangan distribusi pendapatan di suatu negara, maka akan menimbulkan dampak negatif terhadap pertumbuhan ekonomi, dimana pertumbuhan ekonomi akan mengalami penurunan. Kesenjangan pendapatan terjadi tidak hanya di negara yang sedang berkembang saja, tetapi juga terjadi di negaranegara maju. Perbedaannya adalah di negara berkembang, kesenjangan pendapatan lebih besar dingandingkan dengan negara maju, hal ini terjadi karena di negara maju tingkat pendapatannya cenderung lebih tinggi dan merata.

Todaro (1981) menjelaskan bahwa negara-negara maju secara keseluruhan memperlihatkan pembagian pendapatan yang lebih merata dibandingkan dengan negara-negara dunia ketiga yakni negara-negara yang tergolong sedang berkembang. Tidak ada satu negara pun yang memperlihatkan pemerataan sempurna dan ketidakmerataan sempurna di dalam distribusi pendapatannya, semua kurva Lorenz dari setiap negara akan berada di sebelah kanan garis diagonal seperti ditunjukkan pada Gambar 3. Semakin parah tingkat ketidakmerataan atau distribusi pendapatan di suatu negara, maka $\mathbf{1 2 2}$ | Jurnal Akuntansi AKTIVA 
bentuk kurva Lorenznya pun akan semakin melengkung mendekati sumbu horizontal bagian bawah. Todaro (2006) memberikan batasan bahwa negara-negara yang kesenjangannya tinggi maka koefisien gininya terletak antara 0,50 sampai 0,70 , sedangkan untuk negara-negara yang kesenjangannya relatif rendah atau merata koefisien gininya terletak antara 0,20 sampai 0,35

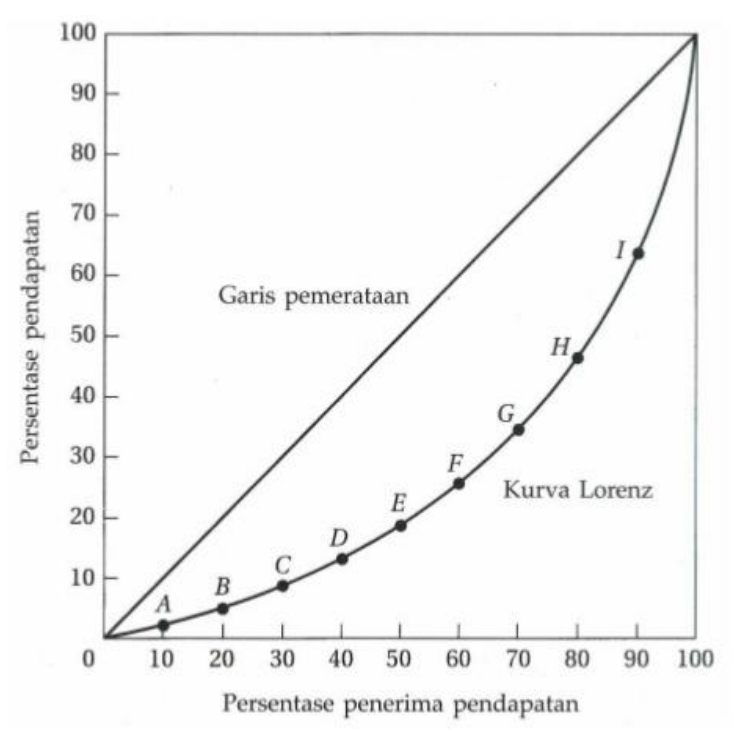

Gambar 3. Kurva Lorenz

Sumber: Todaro, 2006

Koefisien Gini dan Ukuran Kesenjangan Agregat merupakan perangkat yang sangat mudah digunakan untuk mengukur derajat kesenjangandistribusi pendapatan relatif di suatu negara yaitu dengan menghitung rasio bidang yang terletak antara garis diagonal dan kurva Lorenz dibagi dengan luas sepatuh segi empat dimana kurva Lorenz itu berada. Koefisien Gini adalah ukuran kesenjangan agregat yang angkanya berkisar antara nol (pemerataan sempurna) hingga satu (ketidakmerataan sempurna). Pada prakteknya, Koefisien Gini untuk negara-negara yang derajat kesenjangannya tinggi berkisar antara 0.50 hingga 0.70 sedangkan untuk negara yang distribusi pendapatannya relatif merata, angkanya berkisar antara 0.20 hingga 0.35 .

\section{Penetapan Upah Minimum}

Para pendukung upah minimum yang lebih tinggi memandang bahwa penetapan upah minimum akan meningkatkan pendapatan para pekerja miskin. Para penentang upah minimum yang lebih tinggi berpendapat bahwa penetapan upah minimum tersebut bukan cara terbaik untuk membantu penduduk miskin. Penetapan upah minimum yang lebih tinggi selain meningkatkan biaya tenaga kerja, sehingga meningkatkan pengangguran, juga kurang tepat sasaran karena mayoritas para pekerja penerima upah minimum tersebut adalah para remaja yang berasal dari kelompok rumah tangga berpendapatan menengah.

Pasar tenaga kerja dipengaruhi oleh penawaran dan permintaan tenaga kerja. Jika upah minimum berada di atas tingkat keseimbangan upah, maka kuantitas penawaran tenaga kerja akan melebihi jumlah permintaan, sehingga terjadi pengangguran. Walaupun upah minimum meningkatkan 
penghasilan pekerja namun mengurangi kesempatan calon pekerja untuk memperoleh pekerjaan bahkan dapat menimbulkan pemutusan hubungan kerja (PHK) bagi pekerja lainnya.Dampak dari upah minimum terhadap pekerja tergantung pada keahlian dan pengalaman pekerja.Pekerja dengan keahlian yang tinggi dan pengalaman bekerja yang cukup lama biasanya tidak terpengaruh atas kenaikan upah minimum tersebut karena mereka memiliki keseimbangaan tingkat upah yang berada di atas tingkat upah minimum.

\section{Infrastruktur}

Hubungan infrastruktur dengan pembangunan ekonomi, beberapa ahli juga mengungkapkan pendapat mengenai infrastruktur. Menurut Todaro (2006) infrastruktur sebagai salah satu faktor penting yang menentukan pembangunan ekonomi. Hirscman (1958) juga mendefinisikan infrastruktur sesuatu yang sangat dibutuhkan.Tanpa adanya infrastruktur, kegiatan ekonomi pada berbagai sektor ekonomi (industri) tidak dapat berfungsi.

Dalam World Bank Report (Bank Dunia, 1994:12), infrastruktur dibagi dalam 3 golongan, yaitu:

- Infrastruktur ekonomi, merupakan asset fisik yang menyediakan jasa dan digunakan dalam produksi dan konsumsi final, meliputi public utilities (telekomunikasi, sanitasi, air minum, dan gas), public works (bendungan, saluran irigasi, dan drainase), serta sektor transportasi (jalan, kereta api, angkutan pelabuhan, dan lapangan terbang).

- Infrastruktur sosial, merupakan aset yang mendukung kesehatan dan keahlian masyarakat meliputi pendidikan (sekolah dan perpustakan), kesehatan (rumah sakit dan pusat kesehatan), serta untuk rekreasi (museum, taman, dan lain-lain).

- Infrastruktur administrasi atauinstitusi, meliputi penegakan hukum, kontrol administrasi dan koordinasi serta kebudayaan.

Selain itu, Ian Jacob, et all (1994), infrastruktur dibagi menjadi infrastruktur dasar dan infrastruktur pelengkap, sebagai berikut:

- Infrastruktur dasar (basic infrastructure) meliputi sektor-sektor yang mempunyai karakteristik publik dan kepentingan yang mendasar untuk sektor perekonomian lainnya, tidak dapat diperjualbelikan (nontradeble) dan tidak dapat dipisah-pisahkan baik secara teknis maupun spasial. Contohnya jalan raya, kereta api, kanal, pelabuhan laut, bendungan, drainase, dan sebagainya.

- Infrastruktur pelengkap (complementary infrastructure) seperti gas, listrik, telepon, dan pengadaan air minum.

Berdasarkan Peraturan Presiden Nomor 42 Tahun 2005 tentang Komite Percepatan Penyediaan Infrastruktur, menjelaskan mengenai jenis infrastruktur yang diatur oleh pemerintah yaitu 
infrastruktur transportasi, infrastruktur jalan, infrastruktur pengairan, infrastruktur air minum dan sanitasi,infrastruktur telematika, infrastruktur ketenagalistrikan, dan infrastruktur pengangkutan minyak dan gas bumi.

\section{METODE PENELITIAN}

Data yang digunakan Dalam penelitian ini menggunakan data panel yang merupakan gabungan antara data cross section dan timeseries masing-masing variabel periode 2011-2017 dan data cross sectionyang terdiri dari 33 provinsi yang ada di Indonesia, namun provinsi Kalimantan Utara tidak dimasukkan karena merupakan provinsi yang baru ditetapkan oleh Kementerian Dalam Negeri pada tanggal 22 April 2013. Seluruh data yang digunakan adalah data sekunder yang merupakan publikasi dari Badan Pusat Statistik (BPS) dan info lainnya yang bersumber dari studi kepustakaan lain berupa jurnal ilmiah serta buku-buku teks yang menunjang penelitian ini.

\section{Definisi Operasional Variabel}

Tabel 1. Nama Variabel, Simbol, Satuan Pengukuran dan Sumber Data

\begin{tabular}{|c|l|c|c|l|}
\hline No & Nama Variabel & $\begin{array}{l}\text { Simbol } \\
\text { Variabel }\end{array}$ & $\begin{array}{c}\text { Satuan } \\
\text { Pengukuran }\end{array}$ & Sumber Data \\
\hline 1 & Indeks Gini & IG & Persen & $\begin{array}{l}\text { Badan Pusat Statistik } \\
\text { Indonesia }\end{array}$ \\
\hline 2 & $\begin{array}{l}\text { Upah Minimum } \\
\text { Regional Provinsi }\end{array}$ & LogUMR & Persen & $\begin{array}{l}\text { Badan Pusat Statistik } \\
\text { Indonesia }\end{array}$ \\
& Rasio Infrastruktur & R_INF & Rasio & $\begin{array}{l}\text { Badan Pusat Statistik } \\
\text { Indonesia }\end{array}$ \\
\hline
\end{tabular}

\section{Model dan Alat Analisis}

Metode analisis yang dilakukan menggunakan data runtut waktu (time series) dari Tahun 20112017 dan data Cross section yang terdiri dari 33 Provinsi di Indonesia. Model ekonometrika yang akan digunakan untuk menganalisis pengaruh variabel dependen terhadap variabel independen dalam penelitian ini menggunakan persamaan log (logaritma natural) persamaan ini digunakan karena perbedaan satuan antar variable menyamakan satuan antara variabel terikat dan bebas maka data dilakukan persamaan dengan log sehingga dalam persamaan penelitian ini menggunakan persamaan semi Logaritma pada variabel upah minimum regional, maka digunakan model regresi data panel dengan persamaan sebagai berikut :

$$
I G i t=\beta_{0}+\beta_{1} \log U M R_{i t}+\beta_{2} R_{-} I N F_{i t}+\varepsilon_{i t}
$$

IG = Indeks Gini rasio

Log = UMR Upah Minimum Regional

$\mathbf{1 2 5}$ | Jurnal Akuntansi AKTIVA 


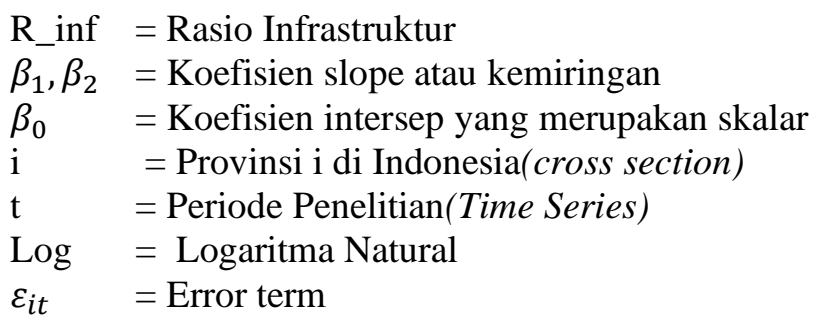

Model OLS digunakan untuk mendapatkan garis regresi yang baik, jika nilai prediksinya sedekat mungkin dengan data aktual atau nilai $\beta_{0}$ dan $\beta_{1}$ yang menyebabkan residual sekecil mungkin. hubungan Y (variabel dependen) dan X (variabel independen) adalah linier dalam parameter, variabel $\mathrm{X}$ atau independen tidak acak atau random. Jika variabel independennya lebih dari satu di dalam regresi berganda maka diasumsikan tidak ada hubungan linier antara variabel independennya (Widarjono, 2017). Untuk menentukan teknik yang paling sesuai untuk melakukan regresi data panel digunakam 3 uji. Pertama, uji statistik F untuk memilih antara metode Pooled Least Square, fixed effect, atau rendom effect. Kedua, melakukan tiga uji yaitu chow test,Lagrage Multiplier, dan Hausman tes.

\section{Pengujian Asumsi Klasik}

Deteksi Multikolinearitas

Adanya dua asumsi penting tentang variabel gangguan yang akan memengaruhi sifat estimator yang BLUE. Pertama, varian dari variabel gangguan adalah tetap atau konstan (homokedastisitas). Kedua, tidak adanya korelasi atau hubungan antara variabel gangguan satu observasi dengan variabel gangguan observasi yang lain atau sering disebut tidak ada masalah autokorelasi (Widarjono, 2013).

Pendeteksian terhadap multikolinieritas dapat dilakukan dengan melihat nilai Variance - Inflating Factor (VIF) dari hasil analisis regresi. Jika nilai VIF>10 maka terdapat gejala multikolinieritas yang tinggi (Sanusi, 2014).

\section{Uji Heterokedastisitas}

Dalam Widarjono (2013) metode OLS mengasumsikan bahwa variabel gangguan mempunyai rata-rata nol, mempunyai varian yang konstan dan variabel gangguan tidak saling berhubungan antara satu observasi dengan observasi lainnya sehingga menghasilkan OLS yang BLUE. Dalam heteroskedastisitas, model regresi tidak memiliki varian yang konstan dengan demikian adanya heteroskedastisitas menyebabkan estimator tidak lagi mempunyai varian yang minimum.Jadi dengan adanya heteroskedastisitas, estimator OLS tidak menghasilkan estimator yang Best Linear Unbiased Estimator (BLUE) hanya Linear Unbiased Estimator (LUE). Terdapat beberapa metode yang digunakan untuk mendeteksi heteroskedastisitas yaitu melalui metode informal, metode park, metode 
Glejser, metode Korelasi Spearman, Metode Goldfeld-Quandt, Metode Breusch-Pagan dan Metode White.

Uji Autokorelasi

Dalam Widarjono (2013) salah satu asumsi penting dalam metode OLS berkaitan dengan variabel gangguan adalah tidak adanya hubungan antara variabel gangguan satu dengan variabel gangguan lain. Sedangkan autokorelasi merupakan adanya korelasi antara anggota observasi satu dengan observasi lain yang berlainan waktu. Dalam kaitannya dengan metode OLS, autokorelasi merupakan korelasi antar satu variabel gangguan dengan variabel gangguan yang lain. Jadi dengan adanya autokorelasi, estimator OLS tidak menghasilkan estimator yang Best Linear Unbiased Estimator (BLUE) hanya Linear Unbiased Estimator (LUE).Terdapat beberapa metode yang digunakan untuk mendeteksi masalah autokorelasi yaitu melalui metode Durbin-Watson, Metode Breusch-Godfrey.

\section{HASIL DAN PEMBAHASAN}

Pemilihan Teknik Estimasi Regresi Data Panel

Uji Chow

Uji Chow dilakukan untuk mengetahui model mana yang lebih baik antara common effect dan fixed effect.

Tabel 2. Hasil Uji Chow

\begin{tabular}{c|c|c|c|c|}
\hline Effect Test & Statistic & $\begin{array}{c}\text { Critical } \\
\text { Value }\end{array}$ & Prob & Kesimpulan \\
\hline $\begin{array}{c}\text { Cross Section Chi } \\
\text { Square }\end{array}$ & 403,0262 & 5,99146 & 0,000 & $\begin{array}{c}\mathrm{H}_{0} \text { ditolak } \\
\mathrm{H}_{8} \text { diterima }\end{array}$ \\
\hline
\end{tabular}

Sumber : Data diolah 2020, Lampiran 10.

Ket : Critical Value pada 0,05

Berdasarkan Uji Chow yang ditunjukkan pada Tabel 2. diperoleh nilai Chi-Square Statistic $(403,0262)>$ Chi Squaretabel $(5,99146)$ pada $\mathrm{df}=2$. Oleh karena itu menolak $\mathrm{H}_{\mathrm{o}}$ dan menerima $\mathrm{H}_{\mathrm{a}}$ sehingga fixed effect model merupakan model yang tepat untuk digunakan pada regresi data panel. 


\section{Pengujian Asumsi Klasik}

Deteksi Multikolinieritas

Dari perhitungan VIF yang ditunjukkan pada Tabel 3. diperoleh nilai VIF $<10$ maka tidak terdapat multikolinieritas. Oleh karena itutidak diperlukan penyembuhan dengan mengeluarkan suatu variabel ketika dihadapkan dengan multikolinearitas yang parah (Gujarati, 1995).

Tabel 3. Uji Multikolinearitas dengan VIF(Variance Inflation Factor)

\begin{tabular}{c|c:c}
\hline Variabel Bebas & VIF & Kesimpulan \\
\hline $\log \mathrm{GMR}$ & 1,015249 & Dalam Taraf Toleransi \\
R INF & 5,886161 & Dalam Taraf Toleransi \\
\hline
\end{tabular}

Sumber :Data diolah 2020.

Deteksi Heterokedastisitas

Tabel 4. Hasil uji Deteksi Heterokedastisitas

\begin{tabular}{|c|c|c|c|}
\hline $\begin{array}{c}\text { Variabel } \\
\text { Terikat }\end{array}$ & $\begin{array}{c}\text { Chi Square } \\
\text { Hitung }\end{array}$ & $\begin{array}{c}\text { Chi } \\
\text { Square } \\
\text { Tabel }\end{array}$ & Kesimpulan \\
\hline 1 & 2,484636 & 5,90146 & TerbebasHeterokedastistas \\
\hline
\end{tabular}

Sumber :Data diolah 2020.

Pada Tabel 4. ditunjukkan bahwa Chi-Square hitung $(2,484636)<$ Chi-Square tabel $(5,99146)$ pada df sebesar variabel bebas $=2$ dan tingkat signifikansi 5 persen. Hal ini berarti menolak $\mathrm{H}_{\mathrm{o}}$ makatidak terdapat masalah heterokedastisitas dalam persamaan.terbebas dari masalah Heterokedastisitas (Widarjono, 2013).

Deteksi Autokolerasi

Tabel 5. Hasil Deteksi Masalah Autokorelasi

\begin{tabular}{|c|c|c|c|}
\hline Variabel Terikat & $\begin{array}{c}\text { Chi Square } \\
\text { Hitung }\end{array}$ & $\begin{array}{c}\text { Chi Square } \\
\text { Tabel }\end{array}$ & Kesimpulan \\
\hline 1 & 6,392826 & 3,84 & $\begin{array}{c}\text { Terdapat } \\
\text { MasalahAutokorelasi }\end{array}$ \\
\hline
\end{tabular}


Pada Table 5. ditunjukkan bahwa Chi-Square hitung (6,392826) >Chi-Square tabel $(3,84)$ pada df sebesar panjang kelambanan $=1$ dan tingkat signifikansi 5 persen.Hal ini berarti menerima $\mathrm{H}_{\mathrm{o}}$ maka terdapat masalah autokorelasi dalam persamaan. Oleh karena itu perlu dilakukan metode white untuk menghilangkan masalah autokorelasi dengan mengubah Coef Covariance Methode menjadi White-Cross section dalam panel option sehingga merubah persamaan regresi menjadi terbebas dari masalah autokorelasi (Widarjono, 2013).

\subsection{Hasil Estimasi Regresi Data Panel dengan Model Fixed Effect}

Tabel 6. Hasil Perhitungan Regresi Model Fixed Effect

\begin{tabular}{c:r:r:c}
\hline Variable & Coefficient & Std. Error & \multicolumn{1}{c|}{ t-Statistic } \\
\hline C & 0,39823 & 0,006043 & 65,90605 \\
\hline LogUMR & $-1,70905$ & 3,191492 & $-5,355042$ \\
\hline R_INF & $-0,01743$ & 0,005502 & $-3,169363$ \\
\hline
\end{tabular}

Sumber :Data diolah 2020.

Berdasarkan hasil perhitungan regresi untuk persamaan dengan model Fixed Effect adalah :

$$
\begin{gathered}
\text { IGit }=\beta_{0}+\beta_{1} \log U M R_{i t}+\beta_{2} R_{-} I N F_{i t}+\varepsilon_{i t} \\
\operatorname{Ig}_{i t}=0,39823+(-1,70905)+(-0,01743)+\varepsilon_{i t} \\
{[0,006043][3,191492][0,005502]} \\
R^{2}=0,845429 \\
\text { F-stat }=31,53015
\end{gathered}
$$

\section{Hasil Uji t (Parsial)}

Uji t-statistik dilakukan untuk mengetahui ada atau tidaknya pengaruh antara masingmasing variabel bebas terhadap variabel terikat secara parsial.Uji t-statistik dalam penelitian ini menggunakan tingkat kepercayaan 95\% atau $\alpha=0.05$ dan derajat kebebasan (degree of freedom) diperoleh dari perhitungan $\mathrm{df}=\mathrm{n}-\mathrm{k}-1$ atau $\mathrm{df}=231-2-1=228$.

Tabel 7. Hasil Uji t Metode OLS pada tingkat signifikansi 95\% dan df $=228$

\begin{tabular}{|c|r|c|c|c|c|}
\hline $\begin{array}{c}\text { Variabel } \\
\text { Bebas }\end{array}$ & Koefisisen & thitung & t-tabel & Probabilitas & Kesimpulan \\
\hline R INF & 0,0174 & 3,1603 & 1,6515 & 0,0022 & Ho ditolak \\
\hline UMR & 1,7090 & 5,3550 & 1,6515 & 0,0000 & Ho ditolak \\
\hline
\end{tabular}


Sumber :Data diolah 2020

\section{Hasil Uji F-Statistik}

Uji ini dilakukan untuk mengetahui apakah variabel bebas secara bersama-sama mempunyai pengaruh signifikan atau tidak signifikan terhadap variabel terikat. Penelitian ini dilakukan pada tingkat kepercayaan 95\% $(\alpha=0,05)$ dengan numerator degree of freedom $\left(\mathrm{df}_{1}\right)=\mathrm{k}-1$ atau $\left(\mathrm{df}_{1}\right)=2-1=1$ dan denumerator degree of freedom $\left(\mathrm{df}_{2}\right)=\mathrm{n}-\mathrm{k}$ atau $\left(\mathrm{df}_{2}\right)$ $=231-2=229$.

Tabel 8. Hasil Uji F pada tingkat kepercayaan 95 persen

\begin{tabular}{|c|c|c|c|}
\hline $\begin{array}{c}\text { Variabel } \\
\text { Terikat }\end{array}$ & F-hitung & F-tabel & Kesimpulan \\
\hline 1 & 31,53015 & 2,325893 & Ho ditolak \\
\hline
\end{tabular}

Sumber : Data diolah 2020

\section{Hasil Koefisien Determinasi $\left(R^{2}\right)$}

Berdasarkan regresi pada lampiran, didapatkan R-Squared atau koefisien determinasi dengan nilai 0,845429. Nilai tersebut menunjukkan bahwa Indeks Gini dapat dijelaskan oleh variabel rasio infrastruktur dan upah minimum regional dengan 84,5 persen. Sebanyak 15,5 persen dijelaskan oleh faktor lain diluar model regresi data panel.

\section{Analisis Individual Effect}

Individual effect merupakan nilai individu masing-masing cross-section yang di dapat dari Fixed Effect Model. Dimana C melambangkan atau gambaran dari variabel lain yang tidak diamati dalam model regresi.

Pulau Sumatera memiliki nilai efek terbesar terhadap Indeks Gini adalah ProvinsiSumatera Selatanyang secara positifmempengaruhi Indeks Ginisebesar 0,399973. Hal ini menunjukan adanya pengaruh fungsi dari rasio infrastruktur dan upah minimum regional yang akan sangat membantu Sumatera Selatandalam meningkatkan distribusi pendapatan yang di ukur melalui Indeks Gini. Begitupun juga dengan provinsi di PulauSumateralain yang memiliki nilai individual effect.

Pulau Kalimantan memiliki nilai efek terbesar terhadap Indeks gini adalah Provinsi Kalimantan Baratyang secara positif mempengaruhi Indeks gini sebesar 0,389923. Hal ini menunjukan adanya pengaruh fungsi dari rasio infrastruktur dan upah minimum regional yang akan sangat membantu Provinsi Kalimantan Barat dalam meningkatkan distribusi 
pendapatan yang di ukur melalui Indeks Gini. Begitupun juga dengan provinsi di Pulau Kalimantan lain yang memiliki nilaiindividual effect.

Pulau Sulawesi memiliki nilai efek terbesar terhadap Indeks Gini adalah ProvinsiGorontaloyang secara positif mempengaruhi Indeks Ginisebesar 3,399973. Hal ini menunjukan adanya pengaruh fungsi dari rasio infrastruktur dan upah minimum regional yang akan sangat membantu ProvinsiGorontalodalam meningkatkan distribusi pendapatan yang di ukur melalui Indeks Gini.Begitupun juga dengan provinsi di PulauSulawesi lain yang memiliki nilaiindividual effect.

Pulau Maluku memiliki nilai efek terbesar terhadap Indeks Gini adalah Provinsi Maluku Utara yang secara positif mempengaruhi Indeks Ginisebesar 4,399973hal ini menunjukan adanya pengaruh fungsi dari rasio infrastruktur dan upah minimum regional yang akan sangat membantu Provinsi Maluku Utara dalam meningkatkan distribusi pendapatan yang diukur melalui Indeks Gini. Begitupun juga dengan provinsi di PulauMaluku lain yang memiliki nilaiindividual effect.

Pulau Bali, NTT dan NTB memiliki nilai efek terbesar terhadap Indeks Gini adalah ProvinsiNTTyang secara positif mempengaruhi Indeks Ginisebesar 2,399973.Hal ini menunjukan adanya pengaruh fungsi dari rasio infrastruktur dan upah minimum regional yang akan sangat membantu Provinsi NTTdalam meningkatkan distribusi pendapatan yang di ukur melalui Indeks gini. Begitupun juga dengan provinsi di PulauBali NTT dan NTB lain yang memiliki nilaiindividual effect.

Pulau Papua memiliki nilai efek terbesar terhadap Indeks Gini adalah Provinsi Papua Barat yang secara positif mempengaruhi Indeks Ginisebesar 0, 451403. Hal ini menunjukan adanya pengaruh fungsi dari rasio infrastruktur dan upah minimum regional yang akan sangat membantu Provinsi Papua dan Papua barat dalam meningkatkan distribusi pendapatan yang diukur melalui Indeks Gini. Begitupun juga dengan provinsi di PulauPapua lain yang memiliki nilaiindividual effect.

\section{Pembahasan}

Pengaruh Upah Minimum Regional terhadap Indeks Gini di Provinsi-provinsi di Indonesia

Berdasarkan hasil perhitungan regresi yang telah didapat pada Tabel 6. nilai koefisien regresi upah minimum regional sebesar -1,70905 dengan tingkat kepercayaan 99 persen. Artinya Apabila upah minimum regional mengalami peningkatan sebesar 1 persen makaakan menurunkan Indeks Gini sebesar 1,70905 persen dengan asumsi variabel lain dalam keadaan konstan(ceteris paribus). Pengujian t-statistik upah minimum regional menunjukkan 131 Jurnal Akuntansi AKTIVA 
berpengaruh secara parsial terhadap permintaan indeks gini provinsi-provinsi di Indonesia.Hal ini sesuai dengan hipotesis penelitian bahwa upah minimum regional berpengaruh dan signifikan terhadap Indeks Gini di provinsi-provinsi di Indonesia.

Dari hasil penelitian ini menunjukkan bahwa variabel Upah Minimum Regionalberpengaruh negatif terhadap Indeks Gini. Upah merupakan faktor utama yang dapat mendorong semangat kerja sehingga diharapkan produktifitas perusahaan akan semakin meningkat. Perubahan tingkat upah akan mempengaruhi tinggi rendahnya biaya produksi perusahaan. Di Indonesia kesenjangan pada kenyataannya tidak dapat dihilangkan dalam pembangunan suatu daerah. Adanya kesenjangan, tentu akan memberikan dorongan kepada daerah-daerah yang terbelakang untuk dapat berusaha meningkatkan kualitas hidupnya agar tidak jauh tertinggal dengan daerah sekitarnya. Sehingga daerah-daerah tersebut yang akan bersaing guna meningkatkan kualitas hidupnya, sehingga kesenjangan dalam hal ini memberikan dampak positif pada penetapan upah minimum yang akan menciptakan kesenjangan distribusi pendapatan.

Tingkat upah harus terus di monitoring dan dijaga agar kebijakaan pemerataan ekonomi yang sudah ada bisa berjalan dalam jangka panjang dan lancar demi mengurangi kesenjanganpendapatan dan baik dalam distribusi pendapatan yang ada di berbagai provinsi di Indonesia.Di dalam penelitian ini mengkaji bagaimana tingkat upah regional terhadap distribusi pendapatan apabila disimpulkan tingkat upah memiliki pengaruh terhadap kesenjangan distribusi pendapatan dengan kebijakan yang ada tentunnya pemerintah Presiden Jokowi bisa terus menekan rasio gini kesenjangan dalam pendapatan.

Hal ini sejalan dengan penelitian Muhammad Anshari (2018), berdasarkan hasil Upah Minimum Provinsi memiliki pengaruh yang signifikan dan negatif terhadap ketimpangan pendapatan di seluruh provinsi di Indonesia. Artinya setiap peningkatan yang terjadi pada upah minimum provinsi akan menyebabkan menurun pada ketimpangan pendapatan dan sebaliknya. Hal tersebut menjelaskan bahwa upah minimum provinsi yang semakin tinggi akan menurunkan ketimpangan pendapatan, karena upah minimum provinsi merupakan faktor penting dalam pemertaan ketimpangan pendapatan

Pengaruh Rasio Infrastruktur terhadap Indeks Gini di Provinsi-provinsi di Indonesia

Berdasarkan hasil perhitungan regresi yang telah didapat pada Tabel 6. nilai koefisien regresi investasi Infrastruktur sebesar -0,01743 dengan tingkat kepercayaan 99 persen. Artinya jika infrastruktur mengalami peningkatan atau perubahan sebesar 1 persen, maka akan menurunkan indeks gini sebesar 0,01743 persen dengan asumsi variabel lain dalam 
keadaan konstan ceteris paribus. pengujian t-statistik rasio infrastruktur menunjukkan berpengaruh secara parsial terhadap permintaan indeks gini provinsi-provinsi di Indonesia.

Hal ini sesuai dengan hipotesis penelitian bahwa Rasio Infrastruktur berpengaruh negatifdan signifikan terhadap Indeks Gini di provinsi-provinsi di Indonesia. Darihasil penelitian ini menunjukkan bahwa variabel rasio Infrastruktur berpengaruh negative terhadap Indeks Gini, karena dengan meningkatnya kualitas Infrastruktur kemajuan, kelengkapan dan perbaikan akan meningkatkan Indeks Ginidan menurunkan kesenjangan di berbagai provinsi di Indonesia.

Pembangunan infrastruktur secara masif dan menyebar ke seluruh wilayah Indonesia akan meningkatkan aktivitas ekonomi dan berbagai bidang. Ketersediaan infrastruktur sangatlah penting dalam suatu pembangunantercipta konektivitas yang kuat antarwilayah, menurunkan biaya logistik, memperkecil ketimpangan, meningkatkan kualitas hidup masyarakat, serta memupus kesenjangan ekonomi antar wilayah di Indonesia, yang pada akhirnya akan bermuara pada peningkatan daya saing dan stimulus pertumbuhan ekonomi serta distribusi pendapatan semakin merata, sehingga variabel rasio infrastruktur adalah suatu indikator penting dalam peningkatan Indeks Gini.

Hal ini sejalan dengan penelitian Tampubolon (2013), melakukan studi mengenai Pengaruh Ketersediaan Infrastruktur Terhadap Ketimpangan Pendapatan Per-Kapita: Analisis Provinsi Di Indonesia 2007-2011. Metode yang digunakan yaitu panel. Hasil analisis yang dilakukan: infrastruktur 1) jumlah rasio sekolah dan air berpengaruh negatif terhadap ketimpangan pendapatan. Variabel tersebut memiliki pengaruh yang signifikan dan negatif terhadap ketimpangan distribusi pendapatan sehingga ketimpangan distribusi pendapatan menurun. 2) panjang jalan, rumah sakit dan listrik memiliki pengaruh signifikan dan positif terhadap ketimpangan pendapatan, sehingga tingkat ketimpangan di setiap provinsi naik. Serta lima variabel bebas yang digunakan, tiga diantaranya berpengaruh positif dalam meningkatkan ketimpangan distribusi pendapatan.

\section{SIMPULAN DAN SARAN}

\section{Simpulan}

Berdasarkan hasil analisis faktor-faktor yang mempengaruhi kesenjangan pendapatan di Indonesia selama tahun 2011-2017, diperoleh kesimpulan sebagai berikut:

1. Variabel Upah Minimum Regional berpengaruh negative dan signifikan terhadap Kesenjangan Distribusi Pendapatan di 33 provinsi di Indonesia.

2. Variabel Rasio infrastruktur berpengaruh negative dan signifikan terhadap Kesenjangan Distribusi Pendapatandi 33 provinsi di Indonesia.

Saran

Berdasarkan kesimpulan dari hasil penelitian, maka saran hasil penelitian sebagai berikut: 
1. Pemerintah harus tetap memonitoring tentang UMR di setiap provinsinya. Campur tangan pemerintah diharapkan dapat memperbaiki kegagalan pasar sehingga menjadi lebih efisien dan merata menetapkan batas bawah (price floor) upah di atas titik keseimbangan yang seharusnya, sehingga lebih mensejahterakan para pekerja. Oleh sebab itu, pemerintah harus terus membuat kebijakan yang baik dan adil tentang upah agar distribusi pendapatan bisa terus baik dan merata untuk daerahnya masing-masing.

2. Dalam kebijakan pembangunan pada setiap daerah, pemerintah harus terus memfokuskan pada perbaikan dan menciptakan infrastruktur jalan baru yang dapat menjangkau akses perekonomian untuk desa ke kota atau antar daerah bahkan antar pulau dalam rangka untuk mempercepat akses aktivitas ekonomi. Infrastruktur merupakan sarana investasi jangka panjang, jadi sangat dibutuhkan akses yang mampu menciptakan daerah-daerah ekonomi baru dan menggerakkan roda perekonomian di Indonesia dari Sabang hingga Merauke. Dampak infrastruktur itu bukan hanya kelas menengah perkotaan, tetapi juga di desa-desa. Infrastruktur yang dibangun selain jalan, perlujuga pembenahan dalam air dan listrik.

\section{REFENSI}

Amri, Khairul. (2017). Analisis Pertumbuhan Ekonomidan Ketimpangan Pendapatan: Panel Data 8 Provinsi di Sumatera.Jurnal Ekonomidan Manajemen Teknologi (EMT).

Badan Pusat Statistik. (2017). Rasio Gini Indonesia tahun 1990-2017. Susenas Maret 2016-2017.

Damanik, Anggiat Mugabe., Zulgani.,Rosmeli. (2018). Faktor-faktor yang Mempengaruhi Ketimpangan Pendapatan melalui Pertumbuhan Ekonomi di Provinsi Jambi. E-Jurnal Perspektif Ekonomi dan Pembangunan Daerah Vol. 7 No. 1, Januari - April 2018 ISSN: 23031255 .

Gujarati, Damodar. 2003. Ekonometrika Dasar. (Drs. Ak. SumarnoZain, MBA. Terjemahan). Jakarta: Erlangga. Buku asli diterbitkan tahun 1978.

Kuznets, S. (1955). Economic Growth and Income Inequality. American Economic Review 45(1), 128.

Nella Helena Tampubolon (2013). Pengaruh Ketersediaan Infrastruktur Terhadap Ketimpangan Pendapatan PerKapita: Analisis Provinsi Di Indonesia 2007-2011. Departemen Ilmu Ekonomi Fakultas Ekonomi Dan Manajemen Institut Pertanian Bogor Bogor 2013.

Muhammad Anshari (2018), Analisis Pengaruh Pendidikan, Upah Minimum Provinsi Dan Belanja Modal Terhadap Ketimpangan Pendapatan Di Seluruh Provinsi Di Indonesia .jurnal EcoGenVolume 1, Nomor 3, 5 September 2018 Jurusan Ilmu Ekonomi Fakultas Ekonomi Universitas Negeri Padang. 
Prasetyo, Rindang Bangundan Firdaus, Muhammad. (2009). Pengaruh Infrastruktur Pada Pertumbuhan Ekonomi di Indonesia. Jurnal Ekonomi dan Kebijakan Pembangunan, 2(2): 222236.

Sadono Sukirno, 2006, Makroekonomi : Teori Pengantar, PT Raja Grafindo Persada, Jakarta

Sibarani, Mauritz. (2002). Kontribusi infrastruktur terhadap pertumbuhan ekonomi Indonesia (26 propinsi di Indonesia tahun 1983-1997). Jakarta: FE UI.

Todaro, M.P. dan Smith Stephen. C. (2003). Pembangunan Ekonomi di Dunia Ketiga. Edisi kedelapan. Jilid 2. Jakarta: Erlangga

Todaro, Michael P. \& Stephen C. Smith, (2006). Pembangunan Ekonomi Edisi Kesembilan. Jakarta: Erlangga.

Widarjono Agus. (2013), Ekonometrika Pengantar dan Aplikasinya. Edisi Keempat. UPP STIM YKPN. Yogyakarta.

Widarjono Agus. (2017), Ekonometrika pengantar dan aplikasinya edisi ke empat.Yogyakarta, UPP STIM YKPN

World Economic Forum. 2015. The Global Competitiveness Report 2014 - 2015. Zhang, Xun, Wan, Guanghua, dan Wang, Xu. 2017. Road infrastructure and the share of labor income: Evidence from China's manufacturing sector. Journal Economic Literature D33,E25,H54 